\title{
CD4+ T Lymphocytes Are the Only HIV-1 Reservoir in Individuals Receiving Combination Antiretroviral Therapy...or Not?
}

\author{
Guido Poli* \\ P2/P3 Laboratories,San Raffaele Scientific Institute,Vita-Salute San Raffaele University, Italy
}

Submission: June 28, 2018; Published: August 27, 2018

*Corresponding author: Guido Poli, P2/P3 Laboratories,San Raffaele Scientific Institute,Vita-Salute San Raffaele University, DIBIT-1, Via Olgettina n. 58, 20132, Milano, Italy,Tel: 39-02-263-4909; Fax: 39-02-263-4905; Email: poli.guido@hsrit

\begin{abstract}
The advent of combination Antiretroviral Therapy (cART) has profoundly changed the life expectancy and quality of individuals infected by the human immunodeficiency virus type-1 (HIV-1). Unfortunately, cART cannot eradicate the infection with the consequence that therapy interruption almost inexorably results in the resurgence of virus replication and disease progression. This partial but relevant failure of cART is mostly explained by the very retroviral nature of HIV-1 that integrates as proviral DNA in CD4+ ${ }^{+}$lymphocytes and myeloid cells. While most $\mathrm{T}$ cells die as a direct or indirect consequence of the infection, a few survive and become long-lived reservoirs responsible for viral rebound and disease progression upon therapy suspension. The dominant view is that CD $4^{+} \mathrm{T}$ lymphocytes with a "resting memory" phenotype (and/or related subsets) are the only well-characterized and relevant HIV-1 reservoir responsible for restarting virus replication and diseases progression upon cART suspension. This brief review will analyze their fundamental contribution to the HIV-1 reservoir, but also will provide evidence that infected tissue-resident Central macrophages could also contribute to reignite virus replication upon cART suspension.
\end{abstract}

Keywords: HIV-1; AIDS; cART; reservoir; functional Cure; CD4 T lymphocyte; tissue resident macrophage; dendritic cell; brain; Acquired immunodeficiency syndrome; Nervous system; Inhibitors; Virus; Antiretrovirals; Housekeeping; Pathogenesis; Lymphocytes; Immunodeficiency

Abbreviations: CART: Combination Antiretroviral Therapy; HIV-1/-2: Human Immunodeficiency Type-1 / Type-2; SIV: Simian Immunodeficiency Virus; AIDS: Acquired Immunodeficiency Syndrome; RT: Reverse Transcriptase; PIs: Protease Inhibitors; CNS: Central Nervous System; TRM: Tissue Resident Macrophages; MDM: Monocyte-Derived Macrophages; VCC: Virus Containing Compartments; NHP: Nonhuman Primates

\section{Introduction}

The discovery of the human T-lymphotropic virus 1, HTLV1, in 1980[1], and of HIV-1 shortly after, this latter causing the Acquired Immuno Deficiency Syndrome (AIDS) [2,3], has introduced two novel chapters in Medicine human exogenous retroviruses as relevant pathogenic viruses (in the case of HIV1 with pandemic potential) and antiretroviral agents that have also served as "lead compounds" for other antiviral drugs, as exemplified by the successful use of Protease Inhibitors (PIs) in the therapy of hepatitis $C$ virus[4].

The early identification of CD4 as primary receptor of HIV-[5] has immediately provided a first, correct model of pathogenesis: by infecting $\mathrm{CD}^{+}{ }^{+} \mathrm{T}$ lymphocytes, HIV-1 caused their depletion with the consequent profound immunodeficiency resulting in the AIDS phase of the disease with opportunistic infections and cancers rapidly leading to the death of $>95 \%$ individuals. The successful discovery of antiretrovirals targeting crucial steps [6] of the retroviral life cycle, starting with the inhibitors of Reverse Transcriptase (RT), the key enzyme allowing the conversion of the viral RNA genome into its DNA equivalent capable of integration in the host chromosomes as a provirus, followed by PIs, integrase inhibitors and others has resulted in cART protocols that have completely reversed the "death sentence" previously associated with the diagnosis of HIV infection and AIDS. Early studies have further reinforced the tight association between[7] virus replication, $\mathrm{T}$ lymphocyte depletion and prognosis of infected individuals therefore leading to a "T cell-centric view" of HIV-1 infection, disease progression and its pharmacological control [8, 9].

This view has been further strengthened by the early studies of Robert Siliciano's laboratory demonstrating that a tiny, but highly stable pool of CD4+ T lymphocytes with a "resting memory" phenotype was infected with replication-competent proviruses (therefore capable of spreading the infection to other cells if 
unchecked by antiretrovirals) that was unaffected by cART (that prevents new infections, but cannot eliminate already infected cells).

Other independent laboratories have confirmed and further refined Siliciano's initial discovery while his laboratory updated the estimate of the size of the $\mathrm{T}$ cell reservoir being potentially 60 -fold bigger than initially calculated [12]. The physiology of "resting-memory" $\mathrm{T}$ cells, undergoing homeostatic proliferation in response to constitutively released cytokines and/or to stimulation by persisting low levels of viral antigens[13], would guarantee life-long infection even in the presence of cART and of the at least partially reconstituted immune system. This latter would be, however, "blind" to latently infected T cells expressing too little, if at all, viral antigens to be detected.

A further intriguing aspect of latent $\mathrm{T}$ cell infection (in the presence of cART) was discovered in 2014 when clonally expanded $\mathrm{CD}^{+} \mathrm{T}$ cells carrying HIV-1 proviruses in the same integration sites were demonstrated to contribute to the HIV-1 reservoir, its stability and potential expansion[14-16]. While most of these T cells carry defective proviruses, some of them actually harbor replication-competent HIV-1 therefore potentially contributing to viral spreading upon therapy suspension [17]. This fundamental knowledge on the nature of the cART-resistant HIV-1 reservoir has inspired the design of several experimental protocols, collectively defined as "Shock and Kill" approaches, based on the stimulation of latently infected $\mathrm{CD}^{+} \mathrm{T}$ cells with various pharmacological agents, such as protein kinase $\mathrm{C}$ activators and inhibitors of histone deacetylases (proven in-vitro to be highly effective in awakening latent HIV-1 infection) in the presence of cART to prevent spreading of the virus while potentially eliminate the pool of chronically infected cells either directly or by means of a restored immune function. The results of these approaching have been collectively disappointing [18]. in terms of poor efficacy in the face of a significant toxicity of the drug cocktails[19].

These studies have also confirmed that latently infected $\mathrm{T}$ cell do not die upon virus reactivation (as earlier observed in-vitro) and that even the experimental addition of immune effector cells [20] (such as $\mathrm{CD}^{+} \mathrm{T}$ lymphocytes with cytolytic potential) while effective in eliminating cells carrying defective proviruses ex vivo is much less efficient against those infected with replicationcompetent HIV-[21]. More recently, the opposite approach of "Blocking and Locking" latent HIV-1 proviruses has been gaining more attention $[19,22]$, but the related pharmacologic armamentarium is currently quite limited.

However, a central question remains: is it definitively proven that the only relevant reservoir of replication-competent HIV-1 is limited to certain subsets of $\mathrm{CD}^{+}{ }^{+} \mathrm{T}$ lymphocytes or do other cell types play a relevant role in individuals under cART? The issue is not just a theoretical question in that even eliminating the T cell-based HIV-1 reservoir by "Shock and Kill" or "Block and Lock" strategies might not be necessarily enough to achieve a "functional Cure" if the virus hides in other cell types potentially obeying to at least partially different rules for its latency and replication. In this regard, non-T cell types proven to be infected in-vivo and infectable in-vitro by HIV-1 with potential features of representing viral reservoirs resistant to cART additional to $\mathrm{CD}^{+} \mathrm{T}$ cells include the astrocytes of the Central Nervous System (CNS), myeloid dendritic cells, carrying the virus from peripheral tissue to regional lymph nodes, and follicular dendritic cells of the lymph node germinal centers that, although not infected, adsorb and maintain virions on their surface for long time, as recently debated in a dedicated meeting[21-23]. I will here focus on discussing the essential features of another cell type as candidate HIV-1 reservoir: TheTissue Resident Macrophages (TRM).

\section{Tissue resident macrophages. A candidate HIV-1 reservoir}

The biology of mononuclear phagocyte ontogeny has undergone a "Copernican revolution" in recent years with the demonstration that most TRM, such as the CNS microglia, do not originate from bone marrow precursors but rather by earlier progenitor cells of the yolk sac or fetal liver[24,25]. In the adult life TRM are capable of self-renewal (similar to resting $\mathrm{T}$ cells) and are responsible for housekeeping functions (such as removal of apoptotic bodies) typical of the tissue or organ where they reside[24,25]. It is only as a consequence of an injury, inflammation or infection that bone marrow-derived, circulating monocytes invade the tissue and rapidly differentiate into Monocyte-Derived Macrophages (MDM) that, together with TRM, become activated according to either a pro-inflammatory (M1) or a tissue repairing, anti-inflammatory (M2) mode encompassing several intermediate states[26,27].

HIV-1 infection of brain microglia, and of other TRM, has been recognized in 1986 to be a significant component of AIDS pathogenesis[28,29]. In the absence of cART, it causes (together with the infection of astrocytes) a state of HIV-associated dementia leading to a deadly encephalitis; it is actually perhaps the only clinical condition in which HIV kills directly its host. It is commonly believed that the high levels of viremia of individuals fully depleted of their CD4+ $\mathrm{T}$ lymphocytes in the absence of cART is at least partially sustained by the productive infection of TRM (more difficult to investigate than $\mathrm{T}$ cells for obvious reasons), as also supported by experimental evidence in non-human primates (NHP), as later discussed. Unlike T cells, macrophages are not significantly depleted by HIV-1 infection both in-vivo (as TRM) and in-vitro (mostly studied in in vitro derived MDM), a feature supporting their potential role as reservoir. Furthermore, they display the unique property of accumulating new progeny virions in subcellular compartments, known as "Virus Containing Compartments (VCC)", resulting from the invagination of the plasma membrane, a subcellular structure preexisting the infection that has been defined "a perfect niche" for the virus to hide from the recognition of the immune system as well as from antiretroviral agents[30-32] (Table 1). 
Table 1: Key similarities and differences in HIV-1 infection of T lymphocytes and Macrophages.

\begin{tabular}{|c|c|c|c|}
\hline Feature & T lymphocytes & Macrophages & Notes \\
\hline Entry & $\begin{array}{l}\text { CD4 (primary receptor) } \\
\text { and CCR5 or CXCR4 } \\
\text { (coreceptors) }\end{array}$ & $\begin{array}{l}\text { CD4 (primary receptor) } \\
\text { and CCR5 or CXCR4 } \\
\text { (coreceptors); } \\
\text { phagocytosis of } \\
\text { infected cells? }\end{array}$ & $\begin{array}{l}\text { Macrophages are usually } \\
\text { productively infected in vitro only } \\
\text { by CCR5-dependent viruses }\end{array}$ \\
\hline Cytopathicity & Present, profound & Absent or minimal & $\begin{array}{l}\text { Features observed } \\
\text { both in vivo and in vitro }\end{array}$ \\
\hline $\begin{array}{l}\text { Subcellular } \\
\text { distribution }\end{array}$ & $\begin{array}{l}\text { virion budding at the } \\
\text { plasma membrane }\end{array}$ & $\begin{array}{l}\text { in addition to virion } \\
\text { budding at the plasma } \\
\text { membrane viral } \\
\text { particles actively } \\
\text { accumulate in VCC }\end{array}$ & $\begin{array}{c}\text { Features observed both in } \\
\text { vivo and in vitro. } \\
\text { Infected macrophages } \\
\text { showing VCC have been } \\
\text { described as } \\
\text { "Trojan horses" of infection }\end{array}$ \\
\hline $\begin{array}{l}\text { In vivo } \\
\text { distribution }\end{array}$ & $\begin{array}{l}\text { Primary and secondary } \\
\text { lymphoid organs, } \\
\text { peripheral blood }\end{array}$ & $\begin{array}{l}\text { Organs and tissues; } \\
\text { central role in CNS }\end{array}$ & $\begin{array}{l}\text { While T cells recirculate, } \\
\text { tissue resident } \\
\text { macrophages do not }\end{array}$ \\
\hline $\begin{array}{l}\text { Main clinical } \\
\text { consequences }\end{array}$ & $\begin{array}{c}\text { Profound immunodeficiency } \\
\text { leading to AIDS in the absence } \\
\text { of cART }\end{array}$ & $\begin{array}{l}\text { Dementia and CNS } \\
\text { encephalitis, chronic } \\
\text { inflammation of tissues } \\
\text { and organs }\end{array}$ & $\begin{array}{l}\text { While cART corrects HIV-induced immunodeficiency it does not } \\
\text { effectively reduce the chronic inflammatory state of several tissues } \\
\text { and organs, a feature associated with the increased frequency } \\
\text { of cardiovascular diseases and solid tumors observed in treated } \\
\text { individuals }\end{array}$ \\
\hline
\end{tabular}

A substantial support to the hypothesis that TRM are a relevant candidate HIV-1 reservoir comes from in-vivo studies. Transgenic mice reconstituted only with myeloid cells establish an inducible viral reservoir [33,34], whereas experimental infection of NHP with SIV (a virus highly related to HIV-2), clearly indicates that, in addition to $\mathrm{T}$ cells, this virus can establish a latent, but inducible infection of brain macrophages in the presence of antiretroviral agents effective in suppressing the animal's viremia[35,36]. Finally, it has been indeed estimated by imaging studies that 10 $20 \%$ of individuals under fully suppressive cART (as determined by undetectable levels of viremia) suffer of either HIV-1 replication or HIV-related inflammation in their CNS[37].

\section{Discussion}

There is no question that infection of $\mathrm{CD}^{+} \mathrm{T}$ lymphocytes is "the heart" of HIV-1 pathogenesis as proven by the success of cART in terms of viral suppression and reconstitution of normal or near normal levels of $\mathrm{CD} 4^{+} \mathrm{T}$ lymphocytes with a highly significant impact on the life expectancy of infected individuals. Nonetheless, it should not be forgotten that HIV belongs to the genus of lentiviruses that typically infect myeloid cells at different stages of maturation[38,39]. The evolutionary selection of CD4 as primary entry receptor (together with CCR5 and CXCR4 coreceptors) has expanded and likely diverted the central target of HIV from myeloid cells to $\mathrm{T}$ lymphocytes with the consequence of causing a deadly immunodeficiency far greater than that observed with animal retroviruses. A recent study in which $\mathrm{CD}^{+}{ }^{+} \mathrm{T}$ cells were artificially depleted from SIV-infected macaques has shown a shift to TRM as primary sources of virus replication[40]. Thus, even an obviously desirable "functional Cure" for $\mathrm{CD} 4{ }^{+} \mathrm{T}$ cell might not necessarily eliminate the long-lasting infection in individuals and prevent their capacity to transmit the virus to others.

\section{Conclusion}

There are several evidences supporting the alternative view that the so called "HIV-1 reservoir" is actually a mosaic of different infected cell types (with T lymphocytes at the center stage), as recently debated [23]. Investing all public and private funds to exclusively support scientific efforts focusing on the "T cell only HIV reservoir" may not be necessarily successful if other cell types (such as TRM) indeed play a relevant role in maintaining HIV-1 as a life-long infection in cART treated individuals.

\section{Acknowledgment}

I wish to thank the many collaborators that have dedicated their time, energy and passion in my research Unit to better understand the role of macrophages in HIV-1 infection.

\section{References}

1. Poiesz BJ, Ruscetti FW, Gazdar AF, Bunn PA, Minna JD, et al. (1980) Detection and isolation of type $C$ retrovirus particles from fresh and cultured lymphocytes of a patient with cutaneous T-cell lymphoma. Proc Natl Acad Sci U S A 77(12): 7415-7419.

2. Barre-Sinoussi F, Chermann JC, Rey F, Nugeyre MT, Chamaret S, et al. (1983) Isolation of a T-lymphotropic retrovirus from a patient at risk for acquired immune deficiency syndrome (AIDS). Science 220(4599): 868-871.

3. Gallo RC, Salahuddin SZ, Popovic M, Shearer GM, Kaplan M, et al. (1984) Frequent detection and isolation of cytopathic retroviruses (HTLV-III) from patients with AIDS and at risk for AIDS. Science 224(4648):500503.

4. de Leuw P, Stephan C (2018) Protease inhibitor therapy for hepatitis C virus-infection. Expert Opin Pharmacother 19(6): 577-587.

5. Klatzmann D, Champagne E, Chamaret S, Gruest J, Guetard D, et al. (1984) T-lymphocyte T4 molecule behaves as the receptor for human retrovirus LAV. Nature 312(5996): 767-768. 
6. Seligmann M, Chess L, Fahey JL, Fauci AS, Lachmann PJ, et al. (1984) AIDS--an immunologic reevaluation. N Engl J Med 311(20): 12861292.

7. Palella FJ Jr, Delaney KM, Moorman AC, Loveless MO, Fuhrer J, et al. (1998) Declining morbidity and mortality among patients with advanced human immunodeficiency virus infection. HIV Outpatient Study Investigators. N Engl J Med 338(13): 853-860.

8. Mellors JW, Rinaldo CR, Gupta P, White RM, Todd JA, et al. (1996) Prognosis in HIV-1 infection predicted by the quantity of virus in the plasma. Science 272(2): 1167-1170.

9. Ho DD, Neumann AU, Perelson AS, Chen W, Leonard JM, et al. (1995) Rapid turnover of plasma virions and CD4 lymphocytes in HIV-1 infection. Nature 373(6510): 123-126.

10. Chun TW, Finzi D, Margolick J, Chadwick K, Schwartz D, et al. (1995) In vivo fate of HIV-1-infected T cells: quantitative analysis of the transition to stable latency. Nat Med 1(12): 1284-1290.

11. Chun TW, Carruth L, Finzi D, Shen X, DiGiuseppe JA, et al. (1997) Quantification of latent tissue reservoirs and total body viral load in HIV-1 infection [see comments]. Nature 387(6629): 183-188.

12. Ho YC, Shan L, Hosmane NN, Wang J, Laskey SB, et al. (2013) Replication-competent noninduced proviruses in the latent reservoir increase barrier to HIV-1 cure. Cell 155(3): 540-551.

13. Chomont N, El-Far M, Ancuta P, Trautmann L, Procopio FA, et al. (2009) HIV reservoir size and persistence are driven by T cell survival and homeostatic proliferation. Nature Medicine15(8): 893-900.

14. Maldarelli F, Wu X, Su L, Simonetti FR, Shao W, et al. (2014) HIV latency. Specific HIV integration sites are linked to clonal expansion and persistence of infected cells. Science 345(6193): 179-183.

15. Wagner TA, McLaughlin S, Garg K, Cheung CY, Larsen BB, et al. (2014) HIV latency. Proliferation of cells with HIV integrated into cancer genes contributes to persistent infection. Science 345(6196): 570-573.

16. Cesana D, Santoni de Sio FR, Rudilosso L, Gallina P, Calabria A, et al. (2017) HIV-1-mediated insertional activation of STAT5B and BACH2 trigger viral reservoir in T regulatory cells. Nat Commun 8(1): 498.

17. Simonetti FR, Sobolewski MD, Fyne E, Shao W, Spindler J, et al. (2016) Clonally expanded CD4+ T cells can produce infectious HIV-1 in vivo. Proc Natl Acad Sci U S A 113(7): 1883-1888.

18. Deeks SG (2012) HIV: Shock and kill. Nature 487(7408): 439-440.

19. Gallo RC (2016) Shock and kill with caution. Science 354(6309): 177178.

20. Biswas P, Poli G, Orenstein JM, Fauci AS (1994) Cytokine-mediated induction of human immunodeficiency virus (HIV) expression and cell death in chronically infected U1 cells: do tumor necrosis factor alpha and gamma interferon selectively kill HIV- infected cells? J Virol 68(4): $2598-2604$

21. Huang SH, Ren Y, Thomas AS, Chan D, Mueller S, et al. (2018) Latent HIV reservoirs exhibit inherent resistance to elimination by CD8+ T cells. J Clin Invest 128(2): 876-889.

22. Kessing CF, Nixon CC, Li C, Tsai P, Takata H, et al. (2017) In Vivo Suppression of HIV Rebound by Didehydro-Cortistatin A, a "Block-andLock" Strategy for HIV-1 Treatment. Cell Rep 21(3): 600-611.

23. Psomas CK, Lafeuillade A, Margolis D, Salzwedel K, Stevenson M,et al. (2018) Highlights from the $8^{\text {th }}$ International Workshop on HIV Persistence during Therapy, 12-15 December 2017, Miami, FL, USA. J Virus Erad 4(2): 132-142.
24. Epelman S, Lavine KJ, Randolph GJ (2014) Origin and functions of tissue macrophages. Immunity 41(1): 21-35.

25. Lavin Y, Mortha A, Rahman A, Merad M (2015) Regulation of macrophage development and function in peripheral tissues. Nat Rev Immunol 15(12): 731-744.

26. Sica A, Mantovani A (2012) Macrophage plasticity and polarization: in vivo veritas. J Clin Invest 122(3): 787-795.

27. Alfano M, Graziano F, Genovese L, Poli G (2013) Macrophage polarization at the crossroad between HIV-1 infection and cancer development. Arterioscler thromb vascu biol 33(6): 1145-1152.

28. Koenig S, Gendelman HE, Orenstein JM, Dal Canto MC, Pezeshkpour GH,et al.(1986) Detection of AIDS virus in macrophages in brain tissue from AIDS patients with encephalopathy. Science223(4768): 10891093.

29. Gartner S, Markovits P, Markovitz DM, Betts RF, Popovic M (1986) Virus isolation from and identification of HTLV-III/LAV-producing cells in brain tissue from a patient with AIDS. JAMA 256(17): 2365-2371.

30.Tan J, Sattentau QJ (2013) The HIV-1-containing macrophage compartment: a perfect cellular niche? Trends Microbiol 21(8): 405412.

31. Graziano F, Desdouits M, Garzetti L, Podini P, Alfano M, et al. (2015) Extracellular ATP induces the rapid release of HIV-1 from virus containing compartments of human macrophages. Proc Natl Acad Sci U S A 112(25): E3265-3273.

32. Graziano F, Vicenzi E, Poli G (2016) Immuno-Pharmacological Targeting of Virus-Containing Compartments in HIV-1-Infected Macrophages. Trends Microbiol 24(7): 558-567.

33. Honeycutt JB, Wahl A, Baker C, Spagnuolo RA, Foster J, et al. (2016) Macrophages sustain HIV replication in vivo independently of T cells. J Clin Invest 126(4): 1353-1366.

34. Honeycutt JB, Thayer WO, Baker CE, Ribeiro RM, Lada SM,et al. (2017) HIV persistence in tissue macrophages of humanized myeloid-only mice during antiretroviral therapy. Nat Med 23(5): 638-643.

35. Gama L, Abreu CM, Shirk EN, Price SL, Li M,et al. (2017) Reactivation of simian immunodeficiency virus reservoirs in the brain of virally suppressed macaques. Aids 31(1): 5-14.

36. Spector SA, Rappaport J (2017) HIV cure strategists: ignore the central nervous system at your patients' peril. Aids 31(1): 167-168.

37. Kugathasan R, Collier DA, Haddow LJ, El Bouzidi K, Edwards SG, et al. (2017) Diffuse White Matter Signal Abnormalities on Magnetic Resonance Imaging Are Associated With Human Immunodeficiency Virus Type 1 Viral Escape in the Central Nervous System Among Patients With Neurological Symptoms. Clin Infect Dis 64(8): 10591065.

38. Narayan O, Zink MC(1988) Role of macrophages in lentivirus infections. Advances in Veterinary Science and Comparative Medicine 32: 129-148.

39. Crespo H, Bertolotti L, Juganaru M, Glaria I, de Andres D, et al. (2013) Small ruminant macrophage polarization may play a pivotal role on lentiviral infection. Vet Res 44: 83.

40. Micci L, Alvarez X, Iriele RI, Ortiz AM, Ryan ES, et al. (2014) CD4 depletion in SIV-infected macaques results in macrophage and microglia infection with rapid turnover of infected cells. PLoS Pathog 10(10): e1004467. 
This work is licensed under Creative Commons Attribution 4.0 Licens DOI: 10.19080/AIBM.2018.10.555789
Your next submission with Juniper Publishers will reach you the below assets

- Quality Editorial service

- Swift Peer Review

- Reprints availability

- E-prints Service

- Manuscript Podcast for convenient understanding

- Global attainment for your research

- Manuscript accessibility in different formats ( Pdf, E-pub, Full Text, Audio)

- Unceasing customer service

Track the below URL for one-step submission https://juniperpublishers.com/online-submission.php 